\title{
408. Veränderungen der nahrungsstimulierten Mikrozirkulation des Magen-Darmtraktes nach proximal selektiver und trunculärer Vagotomie
}

\author{
H. J. Andress, R. K. Teichmann ${ }^{1}$, S. Gycha, J. Seifert und W. Brendel \\ Institut für Chirurgische Forschung und Chirurgische Klinik und Poliklinik, \\ ${ }^{1}$ Klinikum Großhadern, Universität München, Marchioninistraße 15, D-8000 München 70
}

\section{Food-Stimulated Gastrointestinal Microcirculation After Proximal Selective and Truncal Vagotomy}

Summary. Dogs that had undergone proximal selective vagotomy (PSV) or truncal vagotomy and pyloroplast (TV) 4 weeks before and control animals received food intragastrally while anaesthetized. Serum gastrin was determined by radioimmunoassay, microcirculation by microspheres. After PSV blood flow no longer increased $60 \mathrm{~min}$ postprandially, and after TV blood flow increased only in the antral mucosa and the duodenal bulb. There was no difference between the hypergastrinemia following PSV and that after TV. In the gastral phase the vagal nerve seems to exert the strongest stimulus on the gastrointestinal blood flow, exept in the antral mucosa and duodenal bulb; this stimulus is not dependent on gastrin.

Key words: Gastrointestinal blood flow - Gastrin - Food - Vagotomies.

Zusammenfassung. In Narkose wurde nach intragastraler Futtergabe bei Kontrollhunden sowie 4 Wochen nach proximal selektiver (PSV) oder trunculärer Vagotomie mit Pyloroplastik (TV) Serum Gastrin radioimmunologisch und die gastrointestinale Durchblutung mittels Microspheres bestimmt. Nach PSV war die Durchblutung 60 min postprandial nicht mehr, nach TV noch in Antrummucosa und Bulbus duodeni stimulierbar. Zwischen der Hypergastrinämie nach PSV und TV bestand kein Unterschied. In der gastralen Phase scheint der N. vagus - gastrinunabhängig - den größten Stimulus auf die gastrointestinale Durchblutung mit Ausnahme von Antrummucosa und Bulbus duodeni auszuüben.

Schliisselwörter: Gastrointestinale Durchblutung - Gastrin - Futterstimulation - Vagotomien.

\section{Simultane Druckmessung mit nachfolgender Computeranalyse im Magen und im Duodenum von Gesunden und Ulcus-Duodeni-Kranken}

\author{
M. Wehrhahn ${ }^{1}$, R. Bittner, J. Frank, A. Mohnhaupt, K. Affeld und H. G. Beger \\ Universitätsklinik Ulm, Abteilung Chirurgie I, Freie Universität Berlin, Klinikum Charlottenburg, \\ ${ }^{1}$ DRK Krankenhaus, Drontheimer Straße, D-1000 Berlin 65
}

\section{Simultaneous Recording of Pressures in the Stomach and Duodenum of Patients with Duodenal Ulcer and Healthy Subjects, with Subsequent Computer Analysis}

\begin{abstract}
Summary. Comparison of healthy subjects and patients with chronic duodenal ulcer reveals no significant differences in the distribution of amplitudes, slopes, and duration of pressure events in the antrum and duodenum, but there are significant differences in the ratio of the contractions of the antrum to those of the duodenum in individual patients, especially in the range of $5-30 \mathrm{~mm} \mathrm{Hg}(P<0.02)$. In this range, for 1 pressure event in the antrum there are 6.6 events in the duodenum of healthy persons, but only 2.3 in the duodenum of patients with duodenal ulcer.
\end{abstract}

Key words: Pressures - Stomach - Duodenum.

Zusammenfassung. Bei Magengesunden und chronisch Ulcus-Duodeni-Kranken bestehen hinsichtlich Verteilung der Häufigkeit der Amplituden, der Steigung und der Dauer von Druckereignissen im Antrum und im Duodenum keine signifikanten Unterschiede. Betrachtet man aber das Verhältnis der Kontraktionen des Antrums zu denen des Duodenums bei den einzelnen Individuen, so finden sich insbesonders im Bereich zwischen 5 und $30 \mathrm{~mm} \mathrm{Hg}$ signifikante Unterschiede $(P<0,02)$. Es zeigt sich, daß in diesem Bereich bei Gesunden auf ein Druckereignis im Antrum im Mittel 6,6 Ereignisse im Duodenum kamen, beim chronisch Ulcuskranken waren es hingegen nur 2,3 Ereignisse.

Schliusselwörter: Drucke - Magen - Duodenum. 